\title{
Diskripsi Perbandingan Histologi Organ Saluran Reproduksi Puyuh yang Diberi Perlakuan Serbuk Kunyit Sebelum Masak Kelamin dan yang Tidak Diberi Perlakuan Serbuk Kunyit
}

\section{Comparison Description Histology Reproductive Tract Organ of Quail that Supplemented by Turmeric Powder Before Sex Mature Period and Not-Supplemented by Turmeric Powder}

\author{
Tyas Rini Saraswati \\ Departemen Biologi Fakultas Sains dan Matematika Universitas Diponegoro \\ Jl. Prof. Soedarto, SH, Tembalang, Semarang \\ Email : tyasrinis63@gmail.com
}

Diterima 8 Juni 2016 / Disetujui 12 Agustus 2016

\begin{abstract}
ABSTRAK
Penelitian ini bertujuan untuk mengetahui histologi organ saluran reproduksi pada puyuh betina umur 9 bulan. Penelitian ini merupakan penelitian deskriptif. 5 ekor puyuh betina diberi perlakuan serbuk kunyit selama 1 bulan sebelum masak kelamin dan 5ekor puyuh betina tidak diberi perlakuan serbuk kunyit. Masingmasing perlakuan dipelihara sampai umur 9 bulan. Pada akhir perlakuan puyuh di dekapitasi, diisolasi organ saluran reproduksi, yaitu magnum, isthmus, dan uterus dan dibuat preperat histologi dengan metode paraffin dan pewarnaan Haematoxylin dan Eosin. Dilakukan deskripsi histologi pada organ magnum, isthmus dan uterus. Berdasarkan hasil penelitian dapat disimpulkan bahwa saluran reproduksi pada puyuh umur 9 bulan yang diberi perlakuan serbuk kunyit selama 1 bulan sebelum masak kelamin berkembang lebih baik dari pada saluran reproduksi puyuh yang tidak diberi perlakuan serbuk kunyit.
\end{abstract}

Kata kunci : histologi saluran reproduksi, puyuh, serbuk kunyit.

\begin{abstract}
This study aimed to understand the organ histology of reproductive tract of quail female at the age of 9 month. This study was a descriptive research. Five quails female were supplemented by turmeric powder for about 1 month before the sexual maturity, and 5 female quails were untreated by turmeric powder. Each treatment were maintained until the age of 9 months. At the end of the research, the quails were decapitated, the reproductive tract organs were isolated, namely : maghnum, isthmus, and uterine. Then, the organs were made histology preparat with paraffin method and stained by Haematoxylin and Eosin. Based on the result of this study, it can be concluded that the reproductive tract of quails female at the age of 9 months treated with turmeric powder for 1 month before sexual maturity developped better than quails's untreated with turmeric powder.
\end{abstract}

Keywords : histology of reproductive tract, quail, turmeric powder

\section{PENDAHULUAN}

Saluran reproduksi pada puyuh berfungsi dalam pembentukan putih telur, membran kerabang serta kerabang telur. Saluran reproduksi puyuh betina terdiri dari infundibulum, magnum, isthmus, uterus, dan vagina. Secara garis besar jaringan penyusun saluran reproduksi terdiri dari tunika serosa, tunika muskularis, tunika mukosa. Mukosa magnum mengandung lipatan primer dan beberapa lipatan sekunder. Mukosa magnum terdiri dari epitel yang dibatasi oleh sel sel epitel kolumner bersilia (non sekretoris), sel goblet (sel 
sekretoris, tidak bersilia), dan terdapat sel kelenjar tubuler di bawah epithelium. Tunika serosa dan tunika muskularis pada magnum sangat tipis.Isthmus tersusun oleh kelenjar yang sebagian besar menyerupai magnum, dengan lipatan sekunder pada mukosa lebih banyak daripada magnum, epithelium berselang seling antara sel bersilia dengan sel sekretoris. Uterus dikenal sebagai kelenjar kerabang. Lipatan mukosa sangat tinggi dan berkelok kelok ( Saraswati 2015).

Putih telur merupakan sumber protein yang diekskresikan serta diakumulasi dalam sel epitelium dan sel kelenjar tubuler. Keberadaan kuning telur dalam magnum merupakan stimulasi dari saluran reproduksi untuk mensekresikan albumen. Sintesis protein terjadi karena konsentrasi RNA dan kecepatan sintesis albumin dari kelenjar tubuler meningkat pada saat pembentukan telur. Protein albumin berupa ovalbumin, ovotransverin dan lisosim disintesis dalam kelenjar tubuler, sementara avidin dan ovomucin disintesis oleh sel goblet. Pembentukan membran kerabang telur terjadi di isthmus.Kerabang telur terdiri atas dua bagian, yakni kerabang tipis (membran) dan kerabang telur keras. Membran tersusun atas protein yang berbentuk serat dan berikatan dengan keratin tetapi juga kolagen yang mengandung hidroksiprolin dan hidroksilisin serta elastin. Kerabang telur secara umum terdiri atas air, protein, dan bahan kering terutama $\mathrm{CaCO}_{3}$ dan sisanya berupa $\mathrm{MgCO}_{3}$ serta $\mathrm{Ca}_{3}\left(\mathrm{PO}_{4}\right)_{2}$ (Yuwanta 2004; Suprijatna et al. 2005).

Semakin banyak ovum yang diovulasikan maka semakin aktif sel-sel pada saluran reproduksi untuk mensintesis bahan pembentuk putih telur dan kerabang telur, sehingga dapat mempengaruhi perkembangan sel-sel pada saluran reproduksi, yang berakibat pada perubahan histologi saluran reproduksi. Perkembangan sel pada saluran reproduksi juga dirangsang oleh hormon estrogen dan progesteron. Kunyit mengandung fitoestrogen yang mempunyai aktivitas mirip estrogen (Patisaul and Jefferson 2010). Pemberian serbuk kunyit dapat memacu perkembangan saluran reproduksi (Saraswati et al 2014). Kurkumin dalam kunyit juga diketahui membantu proses perbaikan fungsi hati (Yarru et al. 2009; Somchit et al 2005 ). Fitoestrogen pada kunyit juga diketahui memacu biosintesis vitelogenin ( Saraswati et al 2013) sebagai bahan pembentuk kuning telur yang akan dibawa ke ovarium ( Ito et al 2003). Semakin banyak vitelogenin yang terbentuk maka hirarki folikel yang berkembang semakin banyak dan ovum yang diovulasikan akan semakin meningkat ( Saraswati et al 2013).

Berdasarkan hal tersebut maka dilakukan penelitian tentang perbandingan gambaran histologi saluran reproduksi puyuh yang diberi perlakuan serbuk kunyit dan yang tidak diberi perlakuan serbuk kunyit.

\section{METODE PENELITIAN}

Sepuluh ekor puyuh betina umur 1 hari dibagi menjadi 2 kelompok, 5ekor puyuh diberi perlakuan serbuk kunyit selama 1 bulan sebelum masak kelamin, dan 5 ekor tidak diberi perlakuan serbuk kunyit. Hewan uji dipelihara selama 9 bulan diberi pakan komersial. Makan dan minum diberi secara ad libitum. Pada akhir penelitian hewan di dekapitasi, diisolasi organ saluran reproduksi. Dibuat preparat histology magnum, isthmus dan uterus dengan menggunakan metode paraffin dan pewarnaan dengan Haematoxylin dan Eosin . Dilakukan analisis deskriptif gambaran histologi magnum, isthmus dan uterus.

\section{HASIL DAN PEMBAHASAN}

Gambaran histologi saluran reproduksi (oviduk) dapat dilihat pada gambar 1a, 1b, 2a, 2b, 3a, 3b. Saluran reproduksi puyuh terdiri dari lima bagian yaitu: infundibulum (tempat fertilisasi), magnum (tempat produksi putih telur), ithmus (pembentukan membrane kerabang), uterus (pembentukan kerabang telur) dan vagina (oviposisi).

Saluran reproduksi mempunyai struktur yang kompleks untuk menghasilkan komponen telur. Hasil pengamatan histologi saluran reproduksi pada puyuh yang tidak diberi perlakuan serbuk kunyit dan yang diberi perlakuan serbuk kunyit sebelum masak menunjukkan perbedaan 
struktur histologi yang berbeda. Secara garis besar saluran reproduksi terdiri dari tunika serosa, tunika muskularis, tunika mukosa yang melapisi seluruh duktus.

Mukosa magnum mengandung lipatan primer dan beberapa perlakuan mengandung lipatan sekunder. Mukosa magnum terdiri dari epitel yang dibatasi oleh sel sel epitel kolumner bersilia (non sekretoris), sel goblet ( sel sekretoris, tidak bersilia), dan terdapat sel kelenjar tubuler di bawah epithelium. Tunika serosa dan tunika muskularis pada magnum sangat tipis.

\section{HISTOLOGI MAGNUM}

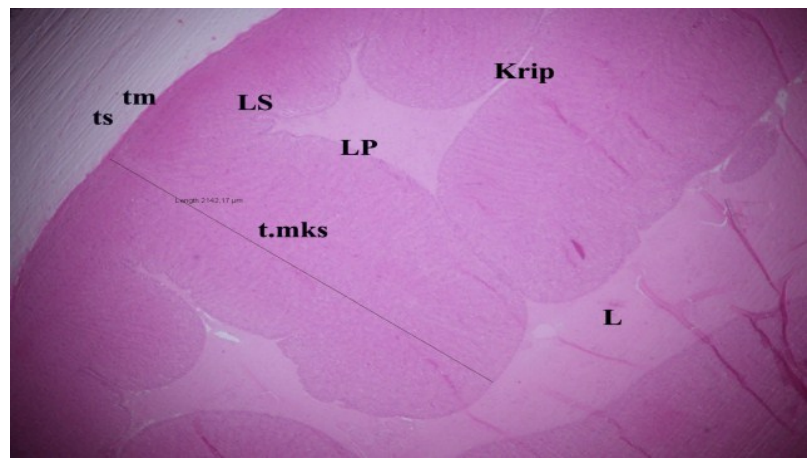

A. Perbesaran $40 \mathrm{x}$

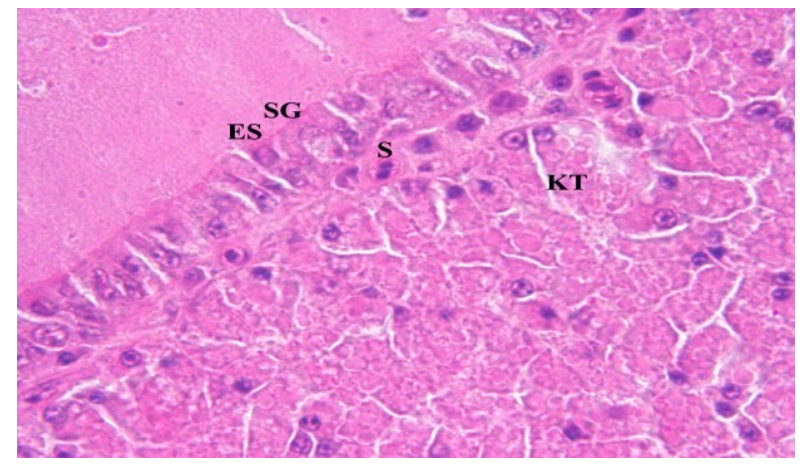

B. Perbesaran 1000x

Gambar 1a. Histologi magnum burung puyuh umur 9 bulan tanpa perlakuan serbuk kunyit

Keterangan :

A. Lapisan dinding magnum :t.serosa (ts), t. muskularis (t.mks), t.mukosa (tm); terdapat lipatan primer(LP) dan lipatan sekunder (LS) dengan invaginasi datar

B. Epitel luminal: kolumner bersilia (ES), sel sekretoris (SG); tampak kelenjar tubuler (KT)

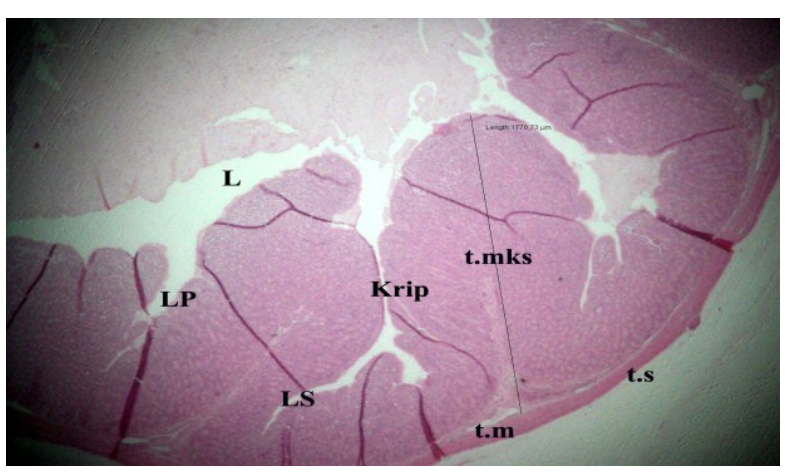

A. Perbesaran $40 \mathrm{x}$

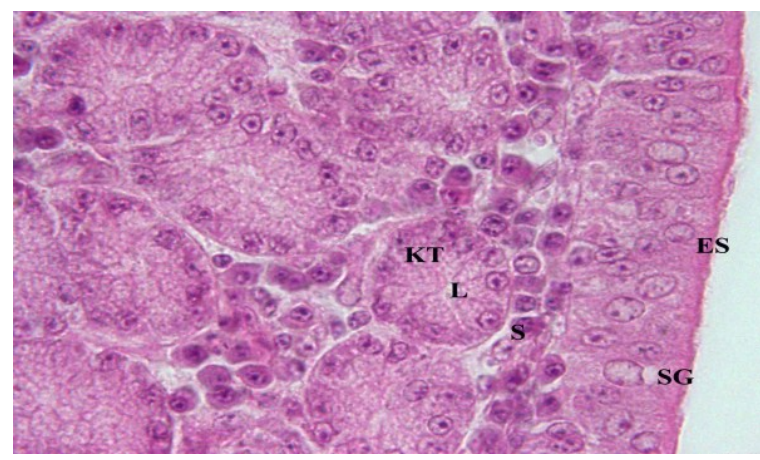

B. Perbesaran 1000x

Gambar 1b. Histologi magnum burung puyuh umur 9 bulan, diberi perlakuan dengan serbuk kunyit 54 $\mathrm{mg} / \mathrm{ekor} /$ hari selama 1 bulan, saat sebelum masak kelamin

Keterangan :

A. Lapisan dinding magnum :t.serosa,t. muskularis,t.mukosa; terdapat lipatan primer(LP) dan lipatan sekunde (LS) dengan invaginasi lebih dalam

B. Epitel luminal: kolumner bersilia (ES), sel sekretoris (SG), stroma (S); tampak kelenjar tubuler (KT) dengan sel berbentuk pyramid lebih berkembang, dengan lumen (L) yang tampak jelas 


\section{HISTOLOGI ISTHMUS}

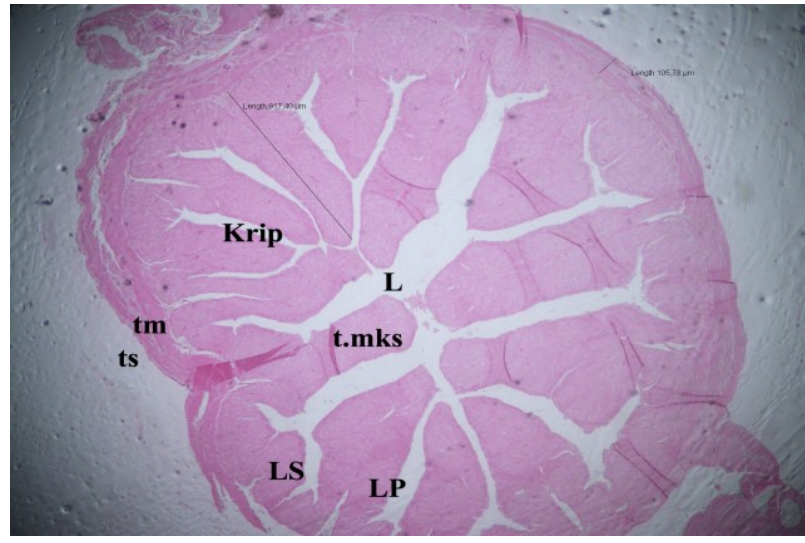

A. Perbesaran $40 \mathrm{x}$

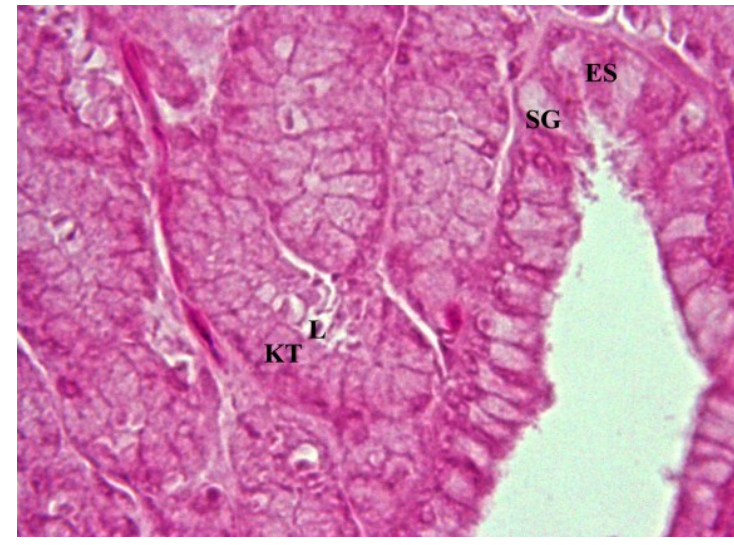

B. Perbesaran 1000x

Gambarb 2a. Histologi isthmus burung puyuh umur 9 bulan, tanpa perlakuan serbuk kunyit

Keterangan :

A. Lapisan dinding isthmus :t.serosa, t. muskularis, t.mukosa; terdapat lipatan primer (LP) dan banyak lipatan sekunder (LS) dengan invaginasi

B. Epitel luminal: sel kolumner bersilia (ES) berselang seling dengan sel sekretoris (SG); tampak kelenjar tubuler yang berkembang dengan baik(KT), tampak lumen (L)

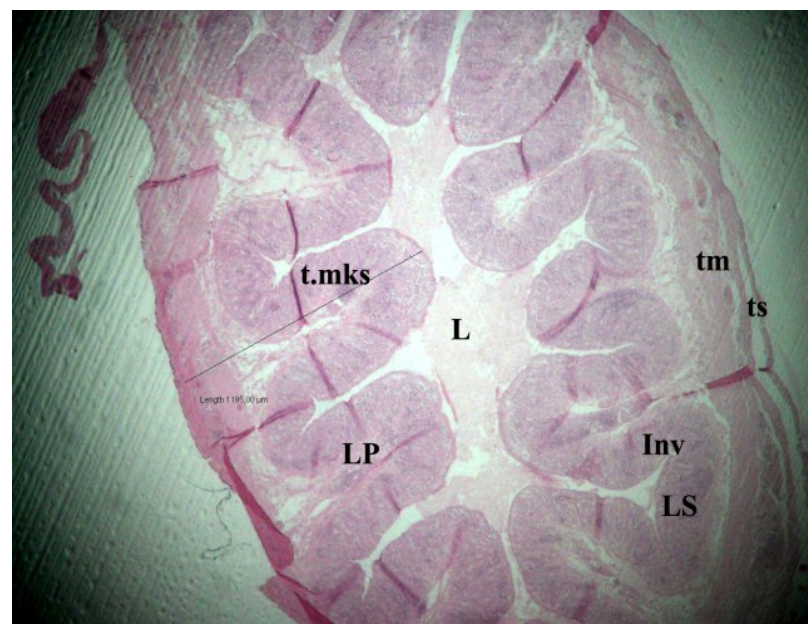

A. Perbesaran 40x

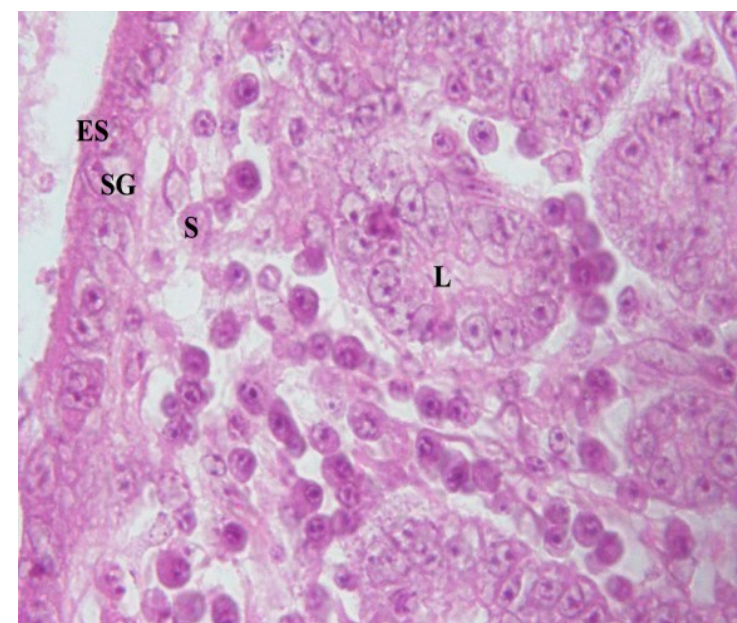

B. Perbesaran 1000x

Gambar 2b. Histologi isthmus burung puyuh umur 9 bulan, diberi perlakuan dengan serbuk kunyit 54 $\mathrm{mg} / \mathrm{ekor} /$ hari selama 1 bulan,saat sebelum masak kelamin.

Keterangan :

A. Lapisan dinding isthmus :t.serosa,t. muskularis,t.mukosa; terdapat lipatan primer(LP) dan banyak lipatan sekunder (LS) dengan invaginasi yang dalam

B. Epitel luminal: kolumner bersilia (ES),berselang seling dengan sel sekretoris (SG); tampak kelenjar tubuler (KT) berkembang baik, stroma (S) berdiferensiasi menjadi kelenjar tubuler 


\section{HISTOLOGI UTERUS}

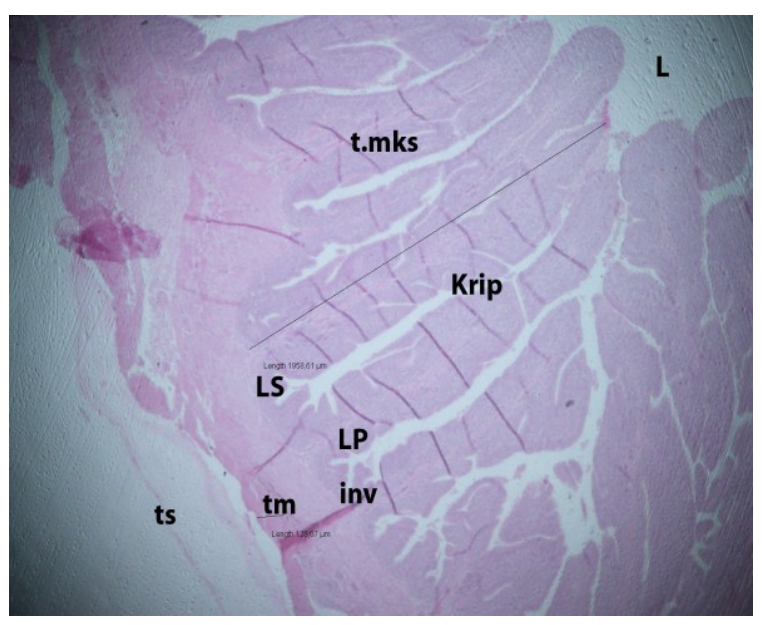

A. Perbesaran $40 \mathrm{x}$

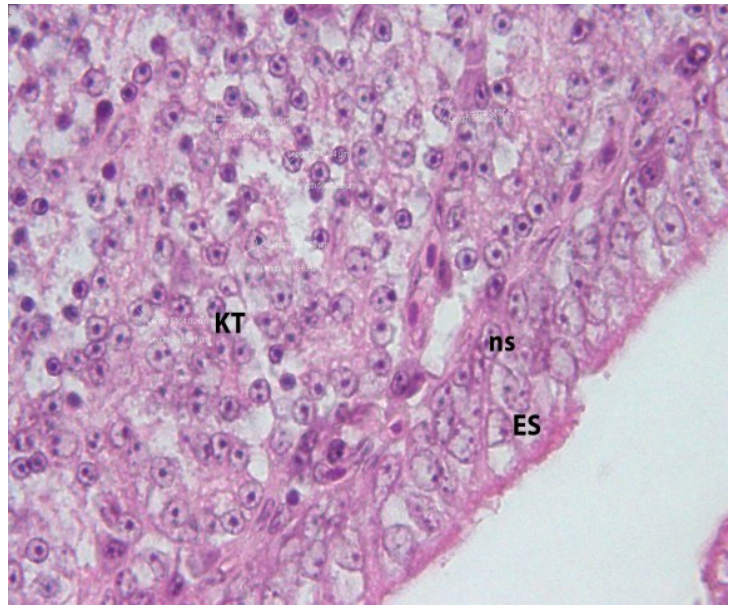

B. Perbesaran 1000x

Gambar 3a. Histologi uterus burung puyuh umur 9 bulan, tidak diberi perlakuan serbuk kunyit

\section{Keterangan :}

A. Lapisan dinding uterus :t.serosa, t. muskularis, t.mukosa; terdapat lipatan primer(LP) pipih tinggi dan banyak lipatan sekunder (LS) dengan invaginasi yang dalam

B. Epitel luminal: tersusun oleh sel kolumner bersilia dengan inti di bagian apikal (ES),sel non silia dengan inti dibagian basal; tampak kelenjar tubuler (KT) berkembang baik, dengan sel berbentuk kuboid

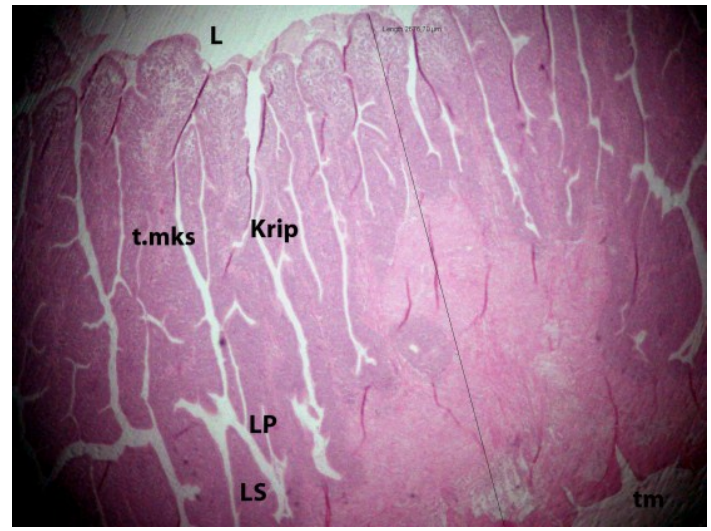

A. Perbesaran 40x

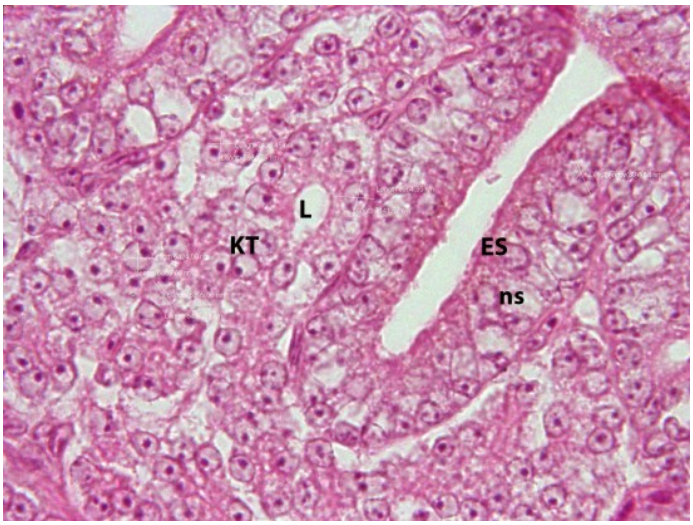

B. Perbesaran $1000 \mathrm{x}$

Gambar 3b. Histologi uterus burung puyuh umur 9 bulan, diberi perlakuan dengan serbuk kunyit 54 $\mathrm{mg}$ /ekor/hari selama 1 bulan, saat sebelum masak kelamin

Keterangan :

A. Lapisan dinding uterus :t.serosa,t. muskularis Menebal),t.mukosa; terdapat lipatan primer(LP) pipih tinggi dan banyak lipatan sekunder (LS) dengan invaginasi yang dalam

B. Epitel luminal: tersusun oleh sel kolumner bersilia dengan inti di bagian apical (ES),sel non silia dengan inti dibagian basal; tampak kelenjar tubuler (KT) berkembang baik, dengan sel berbentuk kuboid, tampak lumen (L) kelenjar 
Magnum dari puyuh yang tidak diberi perlakuan serbuk kunyit (Gambar 1a) menunjukkan lipatan sekunder dengan invaginasi datar, kelenjar tubuler kurang berkembang, sedangkan magnum dari puyuh yang diberi perlakuan serbuk kunyit sebelum masak kelamin (Gambar 1b) menunjukkan bahwa sel epitel kolumner lebih tinggi, sel goblet lebih banyak, lipatan sekunder lebih banyak, dan invaginasi lebih dalam. Terlihat sel sel stroma berdiferensiasi menjadi sel kelenjar tubuler, kelenjar tubuler berkembang dengan baik dengan sel sel kelenjar berbentuk pyramid dengan inti di bagian basal.

Isthmus tersusun oleh kelenjar yang sebagian besar menyerupai magnum, dengan lipatan sekunder pada mukosa lebih banyak daripada magnum, epithelium berselang seling antara sel bersilia dengan sel sekretoris, sel epithelium lebih tinggi daripada sel epithelium pada magnum, tunika muskularis lebih tebal dari magnum. Histologi isthmus pada puyuh yang tidak diberi perlakuan serbuk kunyit (Gambar 2a) : tunika mukosa mempunyai lipatan sekunder yang banyak, sel epithelium kolumner berselang seling dengan sel sekretoris yang jumlahnya banyak, kelenjar tubuler berkembang baik. Isthmus pada puyuh yang diberi perlakuan serbuk kunyit (Gambar 2b) : lipatan sekunder banyak dan melebar dengan invaginasi yang dalam, sel kelenjar tubuler berkembang baik dengan lumen kelenjar terlihat besar, tampak stroma berdiferensiasi menjadi kelenjar tubuler.

Uterus juga dikenal sebagai kelenjar kerabang. Lipatan mukosa sangat tinggi dan berkelok kelok. Sel-sel bersilia dan sel sekretoris yang membatasi epithelium uterus tersusun dalam 1 lapis tunggal, dengan posisi nucleus untuk sel sel bersilia di bagian apical, sedangkan nucleus sel sel sekretoris di bagian basal, sehingga membentuk pseudostratified atau seolah olah tersusun lebih dari satu lapis. Terdapat banyak granula di bagian apical sel epitelium. Silia pada epithelium uterus lebih berkembang dari pada epithelium pada magnum dan isthmus, tunika muskularis lebih tebal. Histologi uterus pada puyuh yang tidak diberi perlakuan serbuk kunyit (Gambar 3a) : Lipatan mukosa sangat tinggi, lipatan sekunder dengan invaginasi yang dalam, sel epithelium bersilia dan sel sekretori berselang seling membentuk lapisan pseudostratified, sel kelenjar berbentuk kuboid dan berkembang baik. Pada uterus puyuh yang diberi perlakuan serbuk kunyit saat sebelum masak kelamin (Gambar 3b) : lipatan mukosa tinggi berkelok kelok, lapisan sekunder banyak berkembang, dengasn invaginasi yang dalam, kelenjar tubuler berkembang baik, dengan lumen yang melebar.

Hasil pengamatan histologi saluran reproduksi pada puyuh umur 9 bulan yang tidak diberi suplemen serbuk kunyit dan yang diberi suplemen srbuk kunyit selama 1 bulan sebelum masak kelamin menunjukkan perbedaan struktur histologi. Berdasarkan gambaran histologi saluran reproduksi baik pada magnum, isthmus, dan uterus membuktikan bahwa saluran reproduksi pada puyuh yang diberi perlakuan dengan serbuk kunyit sebelum masak kelamin, memperlihatkan pertumbuhan lapisan penyusun dinding saluran reproduksi dan sel-sel kelenjar berkembang paling baik.

Perkembangan histologi saluran reproduksi terkait dengan fungsi masing-masing organ dalam mensekresi material telur. Magnum berfungsi penghasil albumin. Sekresi albumin akan terpicu jika ada benda yang masuk ke dalam lumen magnum. Semakin banyak folikel yang diovulasikan semakin aktif sel epithelium maupun sel goblet untuk mensintesis material putih telur. Protein albumin berupa ovalbumin, ovotransverin dan lisosim disintesis dalam kelenjar tubuler, sementara avidin dan ovomucin disintesis oleh sel goblet. Albumin berbentuk kental, berupa gel yang tipis mengandung air. Hasil penelitian (Saraswati et al 2013) menyatakan bahwa pemberian serbuk kunyit meningkatkan perkembangan folikel ovarium, sehingga semakin banyak ovum yang diovulasikan.

Setelah perjalanan di magnum telur bergerak ke isthmus, disini disekresikan kerabang lunak. Kemudian telur tersebut bergerak ke kelenjar kerabang uterus. Kerabang telur secara umum terdiri atas air, protein, $\mathrm{CaCO}_{3}$ dan sisanya berupa $\mathrm{MgCO}_{3}$ serta $\mathrm{Ca}_{3}\left(\mathrm{PO}_{4}\right)_{2}$ (Yuwanta 2004). Kalsium merupakan komponen utama yang 
mempengaruhi kualitas kerabang. Kelebihan atau kekurangan kalsium menurunkan kualitas telur.

\section{SIMPULAN}

Dari hasil penelitian dapat disimpulkan bahwa saluran reproduksi pada puyuh umur 9 bulan yang diberi perlakuan serbuk kunyit selama 1 bulan sebelum masak kelamin berkembang lebih baik dari pada saluran reproduksi puyuh yang tidak diberi perlakuan serbuk kunyit.

\section{DAFTAR PUSTAKA}

Ito $\mathrm{Y}$, Kihara M, Nakamura E, Yonezawa S, Yoshizaki N. 2003. Vitellogenin Transport and Yolk Formation in Quail Ovary. Zoological Science 20:717-726.

Patisaul H.B and Jefferson W 2010. The pros and cons of phytoestrogens. Front Endocrinol:31(4):400-419.

Saraswati T.R. 2015. Telur. Optimalisasi Fungsi Reproduksi Puyuh dan Biosintesis Kimiawi Bahan Pembentuk Telur. Penerbit Leskonfi, Jabar

Saraswati, T.R., W. Manalu., D.R. Ekastuti., N.Kusumorini. 2013. Increase Egg Production of Japanese Quail (Coturnix japonica) by Improving Liver Function Through Turmeric Powder Supplementation. International Journal of poultry Science 12(10):601-614.

Saraswati T.R, Manalu W, Ekastuti D.R, Nastiti K, 2013. The Role of Turmeric Powder in Lipid Metabolism and the Effect on The Quality of The First Quail's Egg. The Journal of The Indonesian tropical Animal Agriculture. Vol 38 no 2.

Saraswati T.R, Manalu W, Ekastuti D.R, Nastiti K. 2014. Effect of Turmeric Powder to Estriol and Progesterone Hormone Profile of Laying Hens During One Cycle of Ovulation. International Journal of Poultry Science 13 (9): 504-509, 2014.
Somchit M.N, Zuraini A, Bustamam A, Sulaiman MR, Nuratunlina R .2005. Protective Activity of Tumeric (Curcuma longa) in Paracetamol Induced-Hepatotoxicity in Rat. International Journal of Pharmacology1(3):252-256,2005

Suprijatna E, Atmomarsono U, Kartasudjana R. 2005. Ilmu Dasar Ternak Unggas. Jakarta.Penebar Semangat

Yarru L.P, Settivari R.S, Gowda N.K.S, Antoniou E, Ledoux D.R, Rottinghaus G.E.2009. Effects of turmeric (Curcuma longa) on the expression of hepatic genes associated with biotransformation, antioxidant, and immune systems in broiler chicks fed aflatoxin. Poultry Science. 2(12): 26202627. 